\title{
HUBUNGAN ANTARA EFIKASI DIRI DENGAN PROKRASTINASI AKADEMIK PADA SISWA KELAS XI SMA NEGERI 9 PADANG
}

\author{
Nelia Afriyeni ${ }^{1}$, Winarno Heru Murjito ${ }^{2}$
}

\begin{abstract}
This research is aimed to know the relationship between self-efficacy and academic procrastination toward students in second year at senior high school state 9 of Padang. Respondents that are used in the research are the students in second year at senior high school state 9 of Padang. The research is conducted to the 66 students in second year and in the academic year of 2008/2009, where the respondents' determination is done by random sampling technique.

The technique of data collecting is used the Likert scale models. That is the scale of self-efficacy and The Procrastination Assesment Scale-Students (PASS) that is developed by Solomon and Rothblum (1994). The methode for analyzing data that is used for testing hyphotesis in the research is the correlation Product Moment (Pearson). Before conducting hyphotesis test, firts, it must done of using test assumptions by normality and linearity test.

The result of data analysis shows efficacy scores are at a moderate scale (60,6\%), and also the procrastination academic scores are at a moderate scale $(72,73 \%)$. From the result of data processing is obtained $p=0,000<0,01$ with a correlation coefficient 0,574 it means hyphotesis is accepted. The result shows there is a negative and significant relationship between self-efficacy and academic procrastination toward the students in the second year at senior high school state 9 of Padang, with the effective contribution of $33 \%$. Thus, it can be concluded that if the higher self-efficacy, then the lower the students' academic procrastination behavior. Conversely, the lower of the self-efficacy, the higher the students' academic procrastination behavior.
\end{abstract}

Keywords: Self-Efficacy, Academic Procrastination, Student

A. Pendahuluan

- ra globalisasi yang menjadikan aliran sumber daya manusia (SDM) menjadi lebih bebas dibandingkan dengan sebelumnya. Hal ini mengakibatkan persaingan yang tajam di antara negaranegara (Nugrasanti, 2006). Penekanan yang sangat kuat terhadap peningkatan kualitas SDM menunjukkan komitmen bangsa yang sangat besar untuk mengejar keunggulan dalam persaingan pada era globalisasi. Orang yang memiliki SDM yang berkualitas tinggi adalah mereka yang mampu menguasai suatu bidang keahlian dalam ilmu pengetahuan dan teknologi, mampu melaksanakan pekerjaan secara profesional, serta mampu menghasilkan karya-karya unggul yang dapat bersaing di dunia (Ghufron, 2003). Seseorang dikatakan mempunyai kualitas sumber daya manusia yang tinggi jika dia dapat menunjukkan perilaku yang mencerminkan adanya kedisiplinan, tidak menyia-nyiakan waktu, kreativitas maupun etos kerja yang tinggi dalam mengerjakan tugas-tugasnya (Ghufron, 2003).

Berhubungan dengan manusia yang berkualitas, dalam dunia psikologi terdapat istilah prokrastinasi yaitu mengenai kebiasaan mengundur waktu pengerjaan tugas. Prokrastinasi merupakan suatu

\footnotetext{
1 The Student of Psychology at the Psychology Faculty of University Putra Indonesia "YPTK" Padang, Indonesia.

${ }^{1}$ The Lecturer of Psychology at the Psychology Faculty of University Putra Indonesia "YPTK"
} 
perilaku menunda mengerjakan tugastugas karena mengalami kecemasan yang subjektif (Solomon \& Rothblum, 1984).

Prokrastinasi merupakan salah satu masalah yang menimpa sebagian besar anggota masyarakat secara luas dan juga pada siswa. Berdasarkan hasil penelitian di Amerika Utara, lebih dari $70 \%$ siswa melakukan prokrastinasi (Schouwenburg, Lay, Pychyl \& Ferrari, 2004). 50\% siswa melakukan prokrastinasi sekurangkurangnya setengah dari waktu mereka, dan $38 \%$ siswa hanya kadang-kadang melakukan prokrastinasi pada tugas akademik (Solomon \& Rothblum dalam Sene'cal, Koestner \& Vallerand, 1995). Pada hasil survey majalah New Statement 26 Februari 1999 (dalam Ghufron, 2003) juga memperlihatkan bahwa kurang lebih $20 \%$ sampai dengan $70 \%$ siswa melakukan prokrastinasi. Lebih dari sepertiga aktivitas sehari-hari mereka pergunakan untuk tidur, bermain atau menonton televisi (Pychyl, Lee, Thibodeau \& Blunt dalam Stell 2007). Semangat belajar mereka semakin lama semakin menipis, dan kalah dengan keinginan untuk bermain. Apalagi saat ini dengan banyak saluran televisi yang bisa dipilih, membuat anak terpaku di depan pesawat televisi. Monks dkk. (dalam Ghufron, 2003) berpendapat bahwa pada remaja terjadi krisis yang nampak paling jelas pada penggunaan waktu luang yang sering disebut sebagai waktu pribadi orang (remaja) itu sendiri. Hal yang dapat dicatat adalah bahwa para remaja mengalami lebih banyak kesukaran dalam memanfaatkan waktu luangnya.

Remaja yang merupakan tunas harapan bangsa diharapkan dapat mempertahankan eksistensi bangsa di era yang akan datang. Maka remaja sudah seharusnya menjadi fokus utama guna mewujudkan sumber daya manusia yang berkualitas agar mereka dapat bersaing dalam era sekarang maupun yang akan datang. Remaja yang saat ini sedang menempuh bangku sekolah merupakan calon kompetitor yang akan menghadapi tingkat persaingan yang tinggi, namun bilamana perilaku prokrastinasi akademik sering dilakukan, akan dapat menjadi masalah tersendiri bagi mereka dan dapat dianggap sebagai salah satu indikator bahwa remaja masih belum bisa diharapkan menjadi sumber daya manusia seperti yang diharapkan (Ghufron, 2003). Maka dapat disimpulkan, prokrastinasi akademik pada remaja atau siswa dapat dikatakan sebagai suatu masalah.

Penundaan pengerjaan tugas terjadi pada lingkungan sekolah (akademik), oleh karena itu dapat diistilahkan dengan prokrastinasi akademik. Menurut Rothblum, Solomon, dan Mukarami (1986), definisi prokrastinasi akademik merupakan kecenderungan dari (a) selalu atau hampir selalu menunda mengerjakan tugas akademik, dan (b) selalu dan hampir selalu mengalami masalah kecemasan yang berhubungan dengan penundaan ini. Tugas-tugas akademik tersebut diantaranya adalah tugas menulis, membaca, belajar menghadapi ujian, menghadiri pertemuan (belajar di sekolah), tugas administratif, dan kinerja akademik secara keseluruhan.

Solomon dan Rothblum (dalam Nugrasanti, 2006) memperkirakan persentase seseorang yang mengalami prokrastinasi cukup tinggi dan cenderung meningkat seiring dengan lamanya masa studi. Berarti jika seorang siswa di masa remaja sudah melakukan prokrastinasi akademik, maka dapat diasumsikan perilaku tersebut akan cenderung meningkat ketika ia memasuki perguruan tinggi. Oleh karena itu, perilaku prokrastinasi pada remaja merupakan masalah yang perlu mendapat perhatian.

Pada tanggal 19 Mei 2008 peneliti melakukan wawancara pada guru BK (Bimbingan dan Konseling) SMA Negeri 9 Padang. Berdasarkan hasil wawancara ini, peneliti mendapat gambaran bahwa siswa kelas $X$ lebih banyak bermasalah dalam hal belajar dari pada siswa kelas XI dan XII, seperti mengerjakan pekerjaan rumah (PR) di sekolah dan menunda-nunda mengerjakan tugas sekolah serta terlambat masuk kelas. Hal ini juga terlihat dari hasil penyebaran kuesioner yang berisi 10 pertanyaan berupa essay pada tanggal 21 Mei 2008 pada 22 Siswa SMA Negeri 9 Padang, diperoleh bahwa siswa tersebut melakukan prokrastinasi, yaitu menunda-nunda dalam memulai atau menyelesaikan tugas yang diberikan guru, mengerjakan tugas (PR) di sekolah atau menjelang tugas akan dikumpulkan 
dengan cara mencontek tugas teman, menunda dalam membaca bahan pelajaran yang ditugaskan oleh guru, dan suka belajar pada malam terakhir atau saat-saat terakhir menjelang ulangan atau ujian. Semua perilaku tersebut dapat dikatakan prokrastinasi akademik karena bersifat penundaan dalam pelaksanaan tugas akademik.

Alasan seseorang melakukan prokrastinasi beraneka ragam. Jika dilihat dari jawaban pemberian kuesioner pada siswa SMA negeri 9 Padang, alasan mereka menunda-nunda mengerjakan tugas atau melakukan prokrastinasi karena kurang mengerti dengan materi tugas atau menganggap tugas tersebut sulit, mengharapkan bantuan teman untuk menyelesaikan tugasnya, malas, tidak mood, dan lebih memilih melakukan kegiatan yang menyenangkan seperti menonton televisi, main games, tidur, dan bermain dengan teman-temannya.

Salah satu alasan yang paling dominan mengapa mereka menunda mengerjakan tugas akademik adalah karena menganggap tugas tersebut sulit. Mereka tidak yakin akan kemampuannya, sehingga menghindar dalam mengerjakan tugas, yang pada akhirnya mengerjakan tugas di saat-saat terakhir pengumpulan, dan cara paling cepat menyelesaikan tugas adalah dengan mencontek tugas teman.

Mengenai keyakinan seseorang akan kemampuannya dalam dunia psikologi disebut dengan istilah efikasi diri. Dimana menurut Bandura (1997), efikasi diri (self efficacy) dinyatakan sebagai keyakinan seseorang akan kemampuannya untuk mengorganisasi dan melakukan tindakan-tindakan yang perlu dalam mencapai tingkat kinerja tertentu. Bandura (dalam Baron \& Byrne, 2002) juga menjelaskan bahwa efikasi diri (self efficacy) adalah evaluasi seseorang terhadap kemampuannya atau kompetensinya untuk melakukan sebuah tugas, mencapai tujuan, atau mengatasi hambatan.

Efikasi diri menentukan pemilihan tingkah laku atau aktivitas yang akan dilakukan. Individu akan dengan yakin melaksanakan dan melakukan aktivitas yang dinilai mampu untuk dilakukannya. Sebaliknya, individu akan cenderung menghindari tugas dan situasi yang dipersepsi melebihi kemampuannya (Bandura, 1986). Hal ini jelaslah, bahwa efikasi diri berhubungan secara langsung dengan prokrastinasi (Bandura; Burka \& Yuen; Judge \& Bono dalam Stell, 2007).

Berdasarkan jawaban yang telah diberikan siswa SMA Negeri 9 Padang, dapat terlihat bahwa keyakinan siswa akan kemampuannya dalam melakukan sebuah tugas, dalam hal ini adalah mengerjakan tugas sekolah akan mempengaruhi cepattidaknya tugas tersebut diselesaikan. Siswa yang berkeyakinan bahwa mereka tidak mampu mengerjakan tugas sekolah (akademik) karena merasa tugas tersebut sulit, maka mereka akan cenderung melakukan prokrastinasi, dan akhirnya mengerjakan tugas di saat-saat terakhir pengumpulan dengan cara mencontek tugas temannya.

Penelitian mengenai prokrastinasi akademik juga pernah diteliti sebelumnya oleh Ghufron (2003) dan Delta (2007). Ghufron (2003) meneliti mengenai prokrastinasi akademik yang dihubungkan dengan kontrol diri dan persepsi remaja terhadap penerapan disiplin orangtua dengan subjek penelitian siswa-siswi Madrasah Aliyah di kota Jogjakarta. Delta (2007) juga meneliti mengenai prokrastinasi akademik dan dihubungkan dengan motivasi berprestasi pada mahasiswa Fakultas Psikologi Universitas Indonesia. Berbeda dengan penelitian sebelumnya, dalam penelitian ini peneliti melihat hubungan antara efikasi diri dengan prokrastinasi akademik. Perbedaan lainnya adalah subjek dan tempat penelitian, dimana peneliti melakukan penelitian pada siswa-siswi SMA Negeri 9 Padang. Hipotesis yang diajukan dalam penelitian ini adalah terdapat hubungan yang negatif antara efikasi diri dengan prokrastinasi akademik pada siswa kelas XI SMA Negeri 9 Padang.

\section{B. Metode \\ a. Subjek Penelitian}

Subjek penelitian ini adalah siswa-siswi kelas XI SMA Negeri 9 Padang tahun ajaran 2008/ 2009 dengan populasi berjumlah 281 orang siswa dan terbagi dalam 8 kelas, yaitu 33 siswa kelas XI IPA1, 33 siswa kelas XI IPA2, 33 siswa 
kelas XI IPA3, 34 siswa kelas XI IPA4, 33 siswa kelas XI IPA5, 38 siswa kelas XI IPS1, 38 siswa kelas XI IPS2, dan 38 siswa kelas XI IPS3. Pemilihan subjek dilakukan secara random dengan sampel penelitian sebanyak 23\% dari jumlah populasi, sehingga sampel dalam penelitian berjumlah 66 orang.

\section{b. Instrumen}

Untuk memperoleh data penelitian digunakan dua skala yaitu skala efikasi diri yang disusun berdasarkan teori dari Bandura (1997) dan The Procrastination Assesment Scale-Students (PASS) yang dikembangkan oleh Solomon dan Rothblum (1994). Setiap pernyataan terdiri empat alternatif jawaban, yaitu STS (Sangat Tidak Sesuai), TS (Tidak Sesuai), S (Sesuai), dan SS (Sangat Sesuai).

\section{c. Metode Analisis Data}

Analisis data yang digunakan dalam penelitian ini adalah analisis Statistika Parametrik dengan teknik Korelasi Produk Moment (Product Moment Correlation) dari Karl Pearson (Hadi, 2004; Nugroho, 2005). Korelasi ini digunakan untuk mengukur kekuatan (keeratan) suatu hubungan antarvariabel.

\section{Hasil}

\section{a. Uji Hipotesis}

Pada hasil uji korelasi didapatkan korelasi yang kuat antara efikasi diri dengan prokrastinasi akademik, yaitu sebesar -0,574 (Nugroho, 2005). Hal ini menunjukkan korelasi negatif, berarti jika efikasi diri siswa rendah maka tinggi perilaku prokrastinasi akademik siswa, dan jika efikasi diri siswa tinggi maka rendah perilaku prokrastinasi akademik siswa tersebut. Hal ini diperkuat dengan hasil uji signifikansi dengan bantuan SPSS versi 12.0 for windows, didapatkan $p$-value

$$
\begin{array}{rr}
X<(\mu-1,0 \sigma) & \text { : Rendah } \\
(\mu-1,0 \sigma) \leq X<(\mu+1,0 \sigma) & \text { : Sedang } \\
(\mu+1,0 \sigma) \leq X & \text { : Tinggi }
\end{array}
$$

sebesar $0,000<0,01$ level of significant $(\alpha)$, dimana menurut Nugroho (2005) Ha diterima, artinya terdapat korelasi yang negatif dan signifikan antara efikasi diri dengan prokrastinasi akademik pada siswa kelas XI SMA Negeri 9 Padang.

Sumbangan efikasi diri terhadap prokrastinasi akademik dapat dilihat pada nilai $\mathrm{R}$ Squared $=0,329$. Artinya sumbangan efektif yang diberikan oleh efikasi diri terhadap prokrastinasi akademik yaitu sebesar $32,9 \%$ dan dibulatkan menjadi 33\%.

\section{b. Analisis Tambahan}

\section{1) Deskripsi Data Penelitian}

Berdasarkan data penelitian yang telah diperoleh dengan pemberian skor pada setiap alternatif jawaban yang diberikan oleh subjek sesuai dengan bobot yang telah diterapkan. Untuk skala efikasi diri, pada jenis aitem favorable skor jawaban $(S T S=1),(T S=2),(S=3)$, dan $(S S=4)$, sedangkan untuk aitem unfavorable skor jawaban (STS $=1)$, $(T S=2),(S=3)$, dan $(S S=4)$. Untuk The Procrastination Assesment Scale-Students (PASS) bagian I, skor jawaban (Tidak pernah $=1$ ), (Jarang $=2)$, $($ Sering $=3$ ) dan (Selalu $=4$ ), sedangkan PASS bagian II dengan skor jawaban (STS = 1), $(\mathrm{TS}=2)$, $(\mathrm{S}=3)$, dan $(S S=4)$. Setelah diberi bobot skor, maka selanjutnya dilakukan pengklasifikasian atau kategorisasi skor jawaban untuk menentukan subjek penelitian tersebut termasuk kelompok tinggi, sedang atau rendah berdasarkan nilai kategori yang telah ditetapkan (Azwar, 2003). Adapun pengklasifikasian subjek dalam penelitian ini, baik untuk variabel efikasi diri maupun variabel prokrastinasi akademik, dibagi dalam 3 bagian yaitu :

Tabel 1

Deskripsi Data Penelitian

\begin{tabular}{ccccc}
\hline Variabel & Min & Max & SD & Mean \\
\hline Efikasi diri & 42 & 168 & 21 & 105 \\
Prokrastinasi akademik & 12 & 48 & 6 & 30 \\
\hline
\end{tabular}


Berdasarkan Tabel 1 di atas, maka subjek dalam penelitian ini dapat dikategorisasikan sebagai berikut:

Tabel 2

Kategori dan Persentase Efikasi Diri Siswa

\begin{tabular}{ccl}
\hline Interval & Frekuensi $(\%)$ & Kategori \\
\hline $42-83$ & $0(0 \%)$ & Rendah \\
$84-125$ & $40(60,6 \%)$ & Sedang \\
$126-168$ & $26(39,4 \%)$ & Tinggi \\
\hline
\end{tabular}

Dari tabel di atas terlihat bahwa tidak ada subjek penelitian yang memiliki efikasi diri yang rendah $(0 \%)$. Persentase tertinggi berada pada kategori sedang $(60,6 \%)$ sebanyak 40 orang siswa, sedangkan siswa yang memiliki efikasi diri yang tinggi sebanyak 26 orang $(39,4 \%)$.

Tabel 3

Kategori dan Persentase Prokrastinasi Akademik Siswa

\begin{tabular}{ccl}
\hline Interval & Frekuensi $(\%)$ & Kategori \\
\hline $12-23$ & $12(18,2 \%)$ & Rendah \\
$24-35$ & $48(72,73 \%)$ & Sedang \\
$36-48$ & $6(9,1 \%)$ & Tinggi \\
\hline
\end{tabular}

Dari tabel di atas terlihat bahwa sebanyak 12 orang siswa memiliki kecenderungan prokrastinasi yang rendah $(18,2 \%)$. Persentase terbanyak berada pada kategori sedang sebanyak 48 orang siswa $(72,73 \%)$, sedangkan sebanyak 6 orang siswa memiliki kecenderungan prokrastinasi akademik yang tinggi $(9,1 \%)$.

\section{2) Korelasi antara Dimensi-Dimensi}

Tabel 4 Korelasi antara Prokrastinasi Akademik dengan Dimensi-Dimensi Efikasi Diri

\begin{tabular}{|c|c|c|c|c|}
\hline \multirow{2}{*}{$\begin{array}{c}\text { Dimensi } \\
\text { Efikasi Diri }\end{array}$} & \multicolumn{3}{|c|}{ Prokrastinasi Akademik } & \multirow{2}{*}{$\begin{array}{l}\text { Kategori Korelasi } \\
\text { (Nugroho, 2005) }\end{array}$} \\
\hline & $\mathrm{P}$ & 桉: & $R$ & \\
\hline Magnitude & 0,000 & 0,01 & $-0,487$ & Kuat \\
\hline Generality & 0,000 & 0,01 & $-0,574$ & Kuat \\
\hline Strength & 0,000 & 0,01 & $-0,517$ & Kuat \\
\hline
\end{tabular}

Dari Tabel 4 terlihat bahwa dimensi generality berkorelasi lebih besar terhadap perilaku prokrastinasi akademik dengan nilai korelasi sebesar $-0,574$. Tidak jauh beda dengan itu, dimensi strength juga memiliki korelasi $-0,517$ terhadap perilaku prokrastinasi akademik. Sedangkan dimensi magnitude hanya berkorelasi 0,487 dengan perilaku prokrastinasi akademik.

Sumbangan dimensi-dimensi efikasi diri terhadap prokrastinasi akademik adalah:

a) Dimensi generality terhadap prokrastinasi akademik $\mathrm{R}$ Squared $=0,330$

\section{Efikasi Diri dengan Prokrastinasi Akademik}

Untuk melihat dimensi efikasi diri yang paling berpengaruh terhadap prokrastinasi akademik maka akan dilihat korelasi yang terjadi antar keduanya. Hasil perhitungan uji korelasi antara dimensi-dimensi efikasi diri dengan prokrastinasi akademik dapat dilihat pada Tabel 4. 
efektif sebesar 23,7\% terhadap prokrastinasi akademik. Dibulatkan menjadi $24 \%$.

\section{3) Gambaran Umum Kondisi Prokrastinasi pada Masing- Masing Area Akademik}

Untuk melihat kondisi prokrastinasi pada masing-masing area akademik dapat dilihat pada tabel berikut ini:

Tabel 5 Kondisi Prokrastinasi Masing-Masing Area Akademik

\begin{tabular}{llcc}
\hline \multicolumn{2}{c}{ Area Akademik yang Diprokrastinasi } & Jumlah & $\%$ \\
\hline 1. & Pekerjaan Rumah (PR) & 334 & $18,06 \%$ \\
2. Belajar menghadapi ujian & 314 & $16,98 \%$ \\
3. Tugas membaca mingguan & 320 & $17,31 \%$ \\
4. Tugas-tugas administrasi & 284 & $15,36 \%$ \\
5. Menghadiri pelajaran di sekolah dan les tambahan & 285 & $15,41 \%$ \\
6. Tugas akademis secara umum & 312 & $16,87 \%$ \\
\hline \multicolumn{2}{c}{ Jumlah } & 1849 & $100 \%$ \\
\hline
\end{tabular}

Dari Tabel 5 di atas terlihat bahwa siswa lebih banyak melakukan prokrastinasi pada pekerjaan rumah (PR) sebesar $18,06 \%$. Selain itu pada tugas membaca mingguan sebesar $17,31 \%$; belajar menghadapi ujian $16,98 \%$; tugas akademis secara umum $16,87 \%$; menghadiri pelajaran di sekolah dan les tambahan $15,41 \%$ dan pada tugas-tugas administrasi sebesar $15,36 \%$.

\section{4) Alasan Melakukan Prokrastinasi Akademik}

Berdasarkan perolehan data dari PASS bagian II dapat dilihat bahwa alasanalasan siswa melakukan prokrastinasi akademik yaitu sebagai berikut:

Tabel 6

Alasan Siswa Melakukan Prokrastinasi Akademik

\begin{tabular}{lcccc}
\multicolumn{1}{c}{ Alasan Prokrastinasi } & $\begin{array}{c}\text { No. } \\
\text { Aitem }\end{array}$ & Jumlah & $\begin{array}{c}\text { Rata-rata } \\
\text { Jumlah }\end{array}$ & $\%$ \\
\hline 1. Kecemasan akan suatu evaluasi & 1 & 170 & 170 & $9,18 \%$ \\
2. Kesulitan membuat keputusan & 2,10 & 178,146 & 162 & $8,75 \%$ \\
3. Ketergantungan dengan orang lain & 16 & 178 & 178 & $9,62 \%$ \\
4. Ancaman dari tugas & 6 & 158 & 158 & $8,54 \%$ \\
5. Rendahnya kepercayaan diri & 5,12 & 147,133 & 140 & $7,56 \%$ \\
6. Kemalasan & 13,17 & 127,132 & 129,5 & $7 \%$ \\
7. Kurangnya penerimaan diri & 4,8 & 169,144 & 156,5 & $8,45 \%$ \\
8. Takut akan berhasil & 11 & 119 & 119 & $6,43 \%$ \\
9. Rendahnya pengaturan waktu & 3,7 & 171,159 & 165 & $8,91 \%$ \\
10. Pemberontakan terhadap peraturan & 15 & 153 & 153 & $8,27 \%$ \\
$\quad$ yang ada & 9 & 180 & 180 & $9,72 \%$ \\
11. Pengambilan resiko & 14 & 140 & 140 & $7,56 \%$ \\
12. Pengaruh teman sebaya & 17 & 2604 & 1851 & $100 \%$ \\
\hline \multicolumn{1}{c}{ Jumlah } & & & & \\
\hline
\end{tabular}

Berdasarkan Tabel 6 di atas dapat diketahui bahwa alasan siswa melakukan prokrastinasi tertinggi adalah karena risk taking (pengambilan risiko) sebesar 9,72\%; alasan kedua karena dependency and help seeking (ketergantungan dengan orang lain) sebesar 9,62\%. Evaluation anxiety (kecemasan akan suatu evaluasi) sebesar $9,18 \%$; serta $8,91 \%$ karena poorly manage time (rendahnya pengaturan waktu); $8,75 \%$ karena difficulty making decisions (kesulitan membuat keputusan); 
$8,54 \%$ karena aversiveness of the task (ancaman dari tugas); 8,45\% karena lack of assertion (kurangnya penerimaan diri); $8,27 \%$ karena rebellion against control (pemberontakan terhadap aturan yang ada); 7,56\% karena lack of self-confidence (rendahnya kepercayaan diri); 7,56\% karena peer influence (pengaruh teman sebaya); 7\% karena laziness (kemalasan); dan alasan terendah sebesar $6,43 \%$ karena fear of succes (takut akan berhasil).

\section{Diskusi}

D ari hasil uji korelasi Product Moment (Pearson) yang dilakukan dengan bantuan SPSS versi 12.0 for windows, dimana level of significant $(\alpha)$ 0,01 dan diperoleh $p=0,000$ serta koefisien korelasi $(r)=-0,574$. Karena $p<$ 0,01 maka hipotesis diterima. Hal ini menunjukkan bahwa terdapat hubungan yang negatif antara efikasi diri dengan prokrastinasi akademik pada siswa kelas XI SMA Negeri 9 Padang. Hubungan negatif antara kedua variabel ini menunjukkan bahwa hubungannya berjalan berlawanan arah, artinya kenaikan skor efikasi diri yang diperoleh subjek diikuti dengan penurunan skor prokrastinasi akademik. Oleh karena penelitian ini dilakukan pada siswa, maka hal ini berarti semakin tinggi efikasi diri rendah maka semakin rendah perilaku prokrastinasi akademik siswa. Sebaliknya, semakin rendah efikasi diri maka semakin tinggi perilaku prokrastinasi akademik siswa.

Kekuatan hubungan antara kedua variabel ini ditunjukkan oleh koefisien korelasi (r) sebesar -0,574. Sedangkan nilai $R$ Squared $=0,329$ artinya sumbangan efektif yang diberikan oleh efikasi diri terhadap prokrastinasi akademik adalah sebesar 33\%. Sedangkan $67 \%$ dipengaruhi oleh faktor lain.

Hasil penelitian ini mendukung teori dan penelitian yang dilakukan Bandura; Burka dan Yuen; Judge dan Bono (dalam Stell, 2007) yang mengatakan bahwa efikasi diri berhubungan langsung dengan prokrastinasi. Menurut Bandura (1986) salah satu fungsi efikasi diri adalah untuk menentukan pemilihan tingkah laku atau aktivitas yang akan dilakukan. Individu akan dengan yakin melaksanakan dan melakukan aktivitas yang dinilai mampu untuk dilakukannya. Sebaliknya, individu akan cenderung menghindari tugas dan situasi yang dipersepsi melebihi kemampuannya.

Selain itu, menurut Ormrod (dalam Assaat, 2007) siswa biasanya memiliki pengertian yang baik tentang apa yang dapat dan apa yang tidak dapat mereka lakukan. Hal ini berarti setiap siswa memiliki keyakinan terhadap kemampuannya dalam melaksanakan tugas akademik, yang disebut dengan efikasi diri.

Berdasarkan pendapat beberapa ahli di atas dapat disimpulkan bahwa jika siswa memiliki keyakinan terhadap kemampuannya dalam melaksanakan tugas akademik, maka siswa tersebut akan yakin mengerjakan tugas akademik dan mereka tidak akan mengundur mengerjakan tugas akademik tersebut, dengan kata lain tidak melakukan prokrastinasi. Sebaliknya, jika siswa tidak memiliki keyakinan terhadap kemampuannya dalam melaksanakan tugas akademik atau merasa tidak mampu, maka mereka akan cenderung menghindari tugas atau melakukan prokrastinasi.

Dari perolehan hasil penelitian didapatkan bahwa efikasi diri siswa kelas XI SMA Negeri 9 Padang, persentase tertinggi berada pada kategori sedang $(60,6 \%)$ yaitu sebanyak 40 orang siswa, pada kategori tinggi sebanyak 26 orang $(39,4 \%)$ dan tidak ada siswa yang memiliki efikasi diri yang rendah. Pada perhitungan prokrastinasi akademik siswa kelas XI SMA Negeri 9 Padang, persentase tertinggi juga berada pada kategori sedang yaitu sebanyak 48 orang siswa $(72,73 \%)$, sebanyak 12 orang siswa memiliki kecenderungan prokrastinasi yang rendah $(18,2 \%)$, sedangkan sebanyak 6 orang siswa memiliki kecenderungan prokrastinasi akademik yang tinggi $(9,1 \%)$. Jadi dapat disimpulkan, dengan adanya efikasi diri yang tinggi, siswa cenderung tidak mengundur mengerjakan tugas akademiknya atau tidak melakukan prokrastinasi akademik.

Dari hasil analisis data diperoleh bahwa hipotesis diterima, hal ini berarti ada hubungan yang signifikan antara 
efikasi diri dengan prokrastinasi akademik. Jika dilihat dari korelasi setiap dimensi efikasi diri dengan prokrastinasi akademik menunjukkan hubungan yang signifikan.

1. Hasil korelasi antara dimensi magnitude (tingkat kesulitan tugas) dengan perilaku prokrastinasi akademik adalah sebesar $-0,487$. Ini menunjukkan hubungan yang negatif, artinya jika siswa merasa mampu dalam melakukan berbagai tugas dengan derajat tugas mulai dari yang sederhana, yang agak sulit, hingga yang sangat sulit (magnitude tinggi), maka siswa cenderung tidak akan melakukan prokrastinasi (prokrastinasi rendah). Sebaliknya jika siswa merasa tidak mampu dalam melakukan berbagai tugas dengan derajat tugas mulai dari yang sederhana, yang agak sulit, hingga yang sangat sulit (magnitude rendah), maka siswa akan cenderung melakukan prokrastinasi (prokrastinasi tinggi).

2. Hasil korelasi antara dimensi generality (luas situasi dan bidang tugas) dengan perilaku prokrastinasi akademik sebesar $-0,574$. Ini menunjukkan hubungan yang negatif, artinya jika siswa yakin akan kemampuannya dalam berbagai situasi tugas, mulai dari dalam melakukan suatu aktivitas atau situasi tertentu hingga dalam serangkaian tugas atau situasi yang bervariasi (generality tinggi), maka siswa cenderung tidak akan melakukan prokrastinasi (prokrastinasi rendah). Sebaliknya, jika siswa merasa tidak yakin akan kemampuannya dalam berbagai situasi tugas, mulai dari dalam melakukan suatu aktivitas atau situasi tertentu hingga dalam serangkaian tugas atau situasi yang bervariasi (generality rendah), maka siswa akan cenderung melakukan prokrastinasi (prokrastinasi tinggi).

3. Hasil korelasi antara dimensi strength (kuatnya keyakinan) dengan perilaku prokrastinasi akademik sebesar 0,517 . Ini juga menunjukkan hubungan yang negatif, artinya jika siswa mempunyai keyakinan yang kuat akan kemampuan yang dimilikinya (strength tinggi), maka siswa cenderung tidak akan melakukan prokrastinasi (prokrastinasi rendah). Sebaliknya, jika siswa tidak mempunyai keyakinan yang kuat akan kemampuan yang dimilikinya (strength rendah), maka siswa cenderung melakukan prokrastinasi (prokrastinasi tinggi).

Data tambahan yang diperoleh dari pengukuran prokrastinasi akademik adalah mengenai gambaran umum kondisi prokrastinasi pada masing-masing area akademik dan alasan-alasan siswa melakukan prokrastinasi akademik (lihat Tabel 5). Siswa lebih banyak melakukan prokrastinasi pada pekerjaan rumah (PR) sebesar $18,06 \%$. Selain itu pada tugas membaca mingguan sebesar $17,31 \%$; belajar menghadapi ujian 16,98\%; tugas akademis secara umum 16,87\%; menghadiri pelajaran di sekolah dan les tambahan $15,41 \%$ dan pada tugas-tugas administrasi sebesar $15,36 \%$. Hasil penelitian ini mendukung penelitian yang telah dilakukan Solomon dan Rothblum (1984), bahwa tugas akademik yang paling banyak diprokrastinasi oleh mahasiswa adalah tugas menulis (46\%). Dalam penelitian ini karena subjek penelitiannya adalah siswa SMA, maka tugas pekerjaan rumah (PR) dapat dikategorikan sebagai tugas menulis. Selain itu dalam penelitian Solomon dan Rothblum (1984), persentase kedua terbanyak adalah tugas membaca $30,1 \%$; belajar menghadapi ujian $27,6 \%$; menghadiri pertemuan (perkuliahan) $23 \%$; pada tugas administrasi 10,6\%; dan tugas akademik secara umum 10,2\%.

Data tambahan berikutnya adalah mengenai alasan-alasan siswa melakukan prokrastinasi. Berdasarkan Tabel 6 dapat diketahui bahwa alasan siswa melakukan prokrastinasi tertinggi adalah karena risk taking (pengambilan risiko) sebesar 9,72\%; alasan kedua karena dependency and help seeking (ketergantungan dengan orang lain) sebesar 9,62\%. Evaluation anxiety (kecemasan akan suatu evaluasi) sebesar $9,18 \%$; serta $8,91 \%$ karena poorly manage time (rendahnya pengaturan waktu); $8,75 \%$ karena difficulty making decisions (kesulitan membuat keputusan); 8,54\% karena aversiveness of the task (ancaman dari tugas); 8,45\% karena lack of assertion (kurangnya penerimaan diri); $8,27 \%$ karena rebellion against control (pemberontakan terhadap aturan yang ada); $7,56 \%$ karena lack of self-confidence 
(rendahnya kepercayaan diri); 7,56\% karena peer influence (pengaruh teman sebaya); 7\% karena laziness (kemalasan); dan alasan terendah sebesar 6,43\% karena fear of succes (takut akan berhasil).

\section{Daftar Pustaka}

Assaat, I. I. (2007). Persepsi atas program akselerasi dan stres akademik. Jurnal Provitae, 3 (1), 29-54.

Azwar, S. (2003). Penyusunan skala psikologi. Yogyakarta: Pustaka Pelajar.

Bandura, A. (1997). Self efficacy: The exercise of control. New York: W. H. Freeman \& Co, Publishers.

. (1986). Social foundations of thought and action: A social cognitive theory. New Jersey: Prentice Hall, Inc.

Baron, R.A, \& Byrne. (2002). Psikologi sosial. Jakarta: Airlangga.

Delta, P.E. (2007). Hubungan antara prokrastinasi akademis dengan motivasi berprestasi pada mahasiswa Fakultas Psikologi Universitas Indonesia. Skripsi (tidak diterbitkan). Depok: Fakultas Psikologi Universitas Indonesia.

Ghufron, M.N. (2003). Hubungan kontrol diri dan persepsi remaja terhadap penerapan disiplin orang tua dengan prokrastinasi akademik. Tesis. Yogyakarta: Universitas Gadjah Mada. Diakses dari http://www.damandiri.or.id pada tanggal 28 Maret 2008.

Hadi, S. (2004). Metodologi research. Jilid 3. Yogyakarta: Andi.

Nugrasanti, R. (2006). Locus of control dan prokrastinasi akademik mahasiswa. Jurnal Provitae, 2 (1), 25-33.

Nugroho, B.A. (2005). Strategi jitu memilih metode statistik penelitian dengan SPSS. Yogyakarta: Andi.

Rothblum, E.D., Solomon, L.J., \& Murakami, J. (1986). Affective, cognitive, and behavioral differences between high and low procrastinators. Journal of Counseling Psychology, 33 (4), 387-394.

Schouwenburg, H.C., Lay, C., Pychyl, T.A., \& Ferrari, J.R. (2004). Counseling the procrastinator in academic settings. Diakses dari http://www. books.apa.orgbooks pada tanggal 7 April 2008.

Sene'cal, C., Koestner, R., \& Vallerand, R.J. (1995). Self-regulation and academic procrastination. The Journal of Social Psychology, 135 (5), 607-619.

Solomon, L.J. \& Rothblum, E.D. (1984). Academic procrastination: Frequency and cognitivebehavioral correlates. Journal of Counseling Psychology, 31 (4), 503-509. (1994). Instrument for Praktis: Procrastination Assessment Scale Students (PASS). Dalam Fisher, J. \& Corcoran, K. (Eds). Measures for Clinical Practice (Volume 2, pp. 446-452). New York: The Free Press. 